Кравчук Ольга Володимирівна аспірантка, Національний університет біоресурсів і природокористування України, суддя Кіровоградського окружного адміністративного суду, вул. Генерала Родимцева, 19, Київ, 03041, тел.: (066) 338-22-22, e-mail: o.kravchuk222@gmail.com, https://orcid.org/0000-0001-7649-0104

\title{
РЕАЛІЗАЦІЯ ПРИНЦИПІВ РІВНОСТІ СТОРІН ТА ДИСПОЗИТИВНОСТІ ПРИ ЗАБЕЗПЕЧЕННІ ПОЗОВУ В АДМІНІСТРАТИВНОМУ СУДОЧИНСТВІ
}

Анотація. Стаття привячена проблематиці дотримання принципів рівності сторін та диспозитивності при забезпеченні позову в адміністративному судочинстві. На підставі аналізу наукових, нормативних джерел, правозастосовчої практики визначено зміст принципів диспозитивності та рівності усіх учасників судового процесу перед законом i судом в адміністративному судочинстві. Зазначено, що в силу особливостей суб'єктного складу публічно-правових спорів такі принципи в адміністративному судочинстві характеризуються рядом особливостей. Зокрема, свій вияв такі особливості знаходять при застосуванні одного з найбільш ефективних засобів досягнення завдань адміністративного судочинства - забезпечення адміністративного позову. Констатовано, що попри очевидну спрямованість інституту забезпечення позову на захист прав позивача, Кодексом адміністративного судочинства України передбачені ефективні процесуально-правові механізми захисту прав відповідача при забезпеченні адміністративного позову, які можуть бути реалізовані на будьякій стадії адміністративного судочинства: право на оскарження судового рішення про забезпечення позову, право подання заяви про скасування заходів забезпечення позову, право ініціювати зміну заходу забезпечення позову, право на відшкодування шкоди, завданої забезпеченням позову, у випадку залишення позову без розгляду, а також закриття провадження у справі або у випадку ухвалення рішення суду щодо повної або часткової відмови у задоволенні позову. Разом 3 тим вімічено недосконалий механізм відшкодування шкоди та запропоновано віднести розгляд відповідних заяв відповідача до повноважень суду, який вживав заходи забезпечення позову.

У підсумку зауважено, що існуюче законодавче регулювання інституту забезпечення позову в адміністративному судочинстві характеризується наявністю достатніх захисних та компенсаторних механізмів для відповідача, які 
дозволяють стверджуватипро дотримання принципіврівності сторін та диспозитивності при забезпеченні адміністративного позову.

Ключові слова: адміністративне судочинство, принципи адміністратвиного судочинства, рівність, диспозитивність, забезпечення позову.

Kravchuk Olha Volodymyrivna Postgraduste student, National University of Life and Environmental Sciences of Ukraine, judge of the Kirovohrad Circuit Administrative Cour, Generala Rodymtseva St., 19, Kyiv, 03041, tel .: (066) 338-22-22, e-mail: o.kravchuk222@gmail.com, https://orcid.org/0000-0001-7649-0104

\title{
IMPLEMENTATION OF THE PRINCIPLES OF EQUALITY OF THE PARTIES AND DISPOSITIVITY IN SECURING A CLAIM IN ADMINISTRATIVE JUDICIAL PROCEEDINGS
}

\begin{abstract}
The article is devoted to the issue of observance of the principles of equality of the parties and dispositiveness in securing the claim in administrative proceedings. Based on the analysis of scientific, normative sources, law enforcement practice, the content of the principles of dispositiveness and equality of all participants in the judicial process before the law and the court in administrative proceedings is determined. It is noted that due to the peculiarities of the subject composition of public law disputes, such principles in administrative proceedings are characterized by a number of features. In particular, such features are manifested in the use of one of the most effective means of achieving the objectives of administrative proceedings securing an administrative lawsuit. It is stated that despite the obvious orientation of the institution of securing a claim to protect the rights of the plaintiff, the Code of Administrative Procedure of Ukraine provides effective procedural and legal mechanisms to protect the rights of the defendant in securing an administrative claim, which can be implemented at any stage of administrative proceedings: the right to appeal against the court decision on securing the claim, the right to file an application for cancellation of measures to secure the claim, the right to initiate a change in the measure of securing the claim, the right to compensation for damages caused by securing the claim, and the closure of proceedings. adoption of a court decision on full or partial refusal to satisfy the claim. At the same time, an imperfect mechanism of compensation for damage was noticed and it was proposed to include the consideration of the relevant applications of the defendant in the powers of the court, which took measures to secure the claim. As a result, it is noted that the existing legal regulation of the institution of securing a claim in administrative proceedings is characterized by the presence of sufficient protective and compensatory mechanisms for the defendant, which allow to assert compliance with the principles of equality of arms and
\end{abstract}


dispositiveness in securing an administrative claim.

Keywords: administrative proceedings, principles of administrative proceedings, equality, dispositiveness, securing a claim.

Постановка проблеми. Частина перша статті 2 Кодексу адміністративного судочинства України (далі - КАС України) проголошує завданням адміністративного судочинства справедливе, неупереджене та своєчасне вирішення судом спорів у сфері публічно-правових відносин 3 метою ефективного захисту прав, свобод та інтересів фізичних осіб, прав та інтересів юридичних осіб від порушень з боку суб'єктів владних повноважень.

Адміністративне судочинство в Україні здійснюється адміністративним судом на засадах верховенства права; рівності усіх учасників судового процесу перед законом і судом; гласності і відкритості судового процесу та його повного фіксування технічними засобами; змагальності сторін, диспозитивності та офіційного з'ясування всіх обставин у справі; обов'язковості судового рішення; забезпечення права на апеляційний перегляд справи; забезпечення права на касаційне оскарження судового рішення у випадках, визначених законом; розумності строків розгляду справи судом; неприпустимості зловживання процесуальними правами; відшкодування судових витрат фізичних та юридичних осіб, на користь яких ухвалене судове рішення (частина третя статті 2 КАС України).

У рішенні у справі про рівність сторін судового процесу від 12 квітня 2012 року № 9-рп/2012 Конституційний Суд України зробив висновок, що кожен (громадянин України, іноземець та особа без громадянства) має гарантовані державою рівні права на захист прав і свобод у судовому порядку та на участь у розгляді своєї справи у визначеному процесуальним законом порядку у судах усіх юрисдикцій, спеціалізацій та інстанцій.

Згідно з рішенням Європейського суду з прав людини у справі «Мала проти України» (заява № 4436/07, п. 48) ключовим для концепції справедливого розгляду справи $\epsilon$ те, щоб сторона не була позбавлена можливості ефективно представляти свою справу в суді та мала змогу нарівні із протилежною стороною користуватися правами, передбаченими принципом рівності сторін (див. рішення у справі «Стіл та Морріс проти Сполученого Королівства» (Steel and Morris v. the United Kingdom; заява № 68416/01, п. 59); принцип рівності сторін вимагає «справедливого балансу між сторонами», і кожній стороні має бути надано відповідну можливість для представлення своєї справи в умовах, що не ставлять iii у суттєво невигідне становище порівняно з іiї опонентом (див. рішення у справі «Волошин проти України» (заява № 15853/08, п. 31), «Лазаренко та інші проти України» (№ 70329/12, п. 36), «Бацаніна проти Росії» (заява № 3932/02, п. 22)). 
Таким чином, згідно з позицією Європейського суду з прав людини принцип рівності є одним з основоположних елементів поняття «право на справедливий судовий розгляд», що гарантоване п. 1 ст. 6 Конвенції; учасник справи нарівні із протилежною стороною повинен користуватися правами, передбаченими принципом рівності сторін; кожна сторона повинна мати розумну можливість ефективно представляти свою позицію в умовах, які не ставлять їі в суттєво менш сприятливе становище в порівнянні з опонентом.

Як слушно зазначає суддя Касаційного адміністративного суду у складі Верховного Суду Я. Берназюк, особливість принципу рівності в адміністративному судочинстві - одночасно і одна з ознак його відмежування від цивільного та господарського процесу, в яких цей принцип, за загальним правилом, однаковою мірою стосується всіх без винятку учасників справи [1].

Одним із найбільш дієвих та ефективних засобів досягнень завдань адміністративного судочинства визнається забезпечення позову.

Разом з тим у науковій літературі поширеною є думка, за якою забезпечення позову в адміністративному судочинстві як інститут, беззастережно спрямований на захист прав позивача, $\epsilon$ винятковим 3 точки зору дотримання принципів рівності сторін та диспозитивності. Для унаочнення такої думки правники покликаються, серед іншого, на положення КАС України, яким ніби-то всупереч принципу диспозитивності до складу суб'єктів ініціювання забезпечення позову включено й адміністративний суд [2, с. 258-259].

Натомість Р. Куйбіда і О. Банчук. слушно зазначають, що рівність прав (обов'язків) не обов'язково означає, що вони мають бути однаковими, вона полягає в тому, що кожна із сторін наділена правами і має обов'язки, адекватні правам і обов'язкам іншої сторони [3, с. 13].

На наше переконання, змістовне наповнення принципів диспозитивності та рівності сторін в адміністративному судочинстві загалом та при забезпеченні адміністративного позову - зокрема, $\epsilon$ специфічним, однак передчасними $\epsilon$ висновки про повне їх вихолощення.

Позивачу і відповідачу повинні бути створені рівні можливості для реалізації права на судовий захист, зокрема, під час застосування в інтересах позивача заходів щодо забезпечення позову відповідачу повинна бути гарантована можливість захисту його прав від безпідставного або ж необгрунтованого забезпечення.

Так, Кодексом адміністративного судочинства України передбачений певний обсяг заходів, спрямованих на реалізацію принципу рівності та захист прав відповідача, зокрема, при застосуванні заходів забезпечення адміністративного позову.

Відповідно, метою статті $\epsilon$ дослідження існуючих правових механізмів 
захисту прав відповідача при забезпеченні адміністративного позову у контексті дотримання приницпів рівності сторін та диспозитивності, виявлення основних проблем реалізації таких механізмів та надання пропозицій щодо їх вирішення.

Аналіз останніх досліджень та публікацій. Приницпи адміністративного судочинства $є$ предметом наукового інтересу широкого кола дослідників. Серед них варто виокремити наукові надбання Р. Куйбіди, О. Константого, В. Скрипченка. Разом з тим, дослідженню інституту забезпечення позову присвячена порівняно невелика кількість робіт. Окремі питання забезпечення позову загалом та вказаного процесуального інституту в адміністративному судочинстві розглядалися, О. Лабанем, О. Одосій, С. Марцинкевичем, О. Шурин.

Виклад основного матеріалу. Насамперед зазначимо, що Кодексом адміністративного судочинства України передбачені процесуально-правові механізми захисту прав відповідача при забезпеченні адміністративного позову, які можуть бути реалізовані на будь-якій стадії адміністративного судочинства. В цілому можна погодитись і з думкою Х.Шухатян, який зазначає, що відповідач починає захист своїх прав 3 моменту отримання ухвали про порушення господарської справи та темпорально продовжує його на протязі усього судового процесу [4, с.136]. Більше того, подання заяви про забезпечення позову, яке передує зверненню до суду із позовною заявою, обумовлює реалізацію відповідних процесуальних механізмів ще до відкриття провадження у справі.

Так, О. Лабань підкреслює, що заходи захисту відповідача, передбачені під час забезпечення позову, можуть бути застосовані до моменту прийняття позовної заяви до розгляду, що, по суті, буде визначати особливий момент, коли особа стає відповідачем, на відміну від інших способів, таких як зустрічний позов і відзив на позовну заяву [5, с. 86].

Зокрема, КАС України передбачена можливість оскарження ухвали про забезпечення позову (частина восьма статті 154). Воднораз, вказана норма містить застереження про те, що оскарження ухвали про забезпечення позову не зупиняє ії виконання, а також не перешкоджає подальшому розгляду справи.

Ухвали про забезпечення позову оскаржуються в апеляційному порядку, що встановлений КАС України. Однак, застосування загального терміну, відведеного апеляційному суду для розгляду відповідної апеляційної скарги, видається нам у даному випадку недоречним. Однією із характеризуючих ознак інституту забезпечення позову є саме його оперативність, тому слід скоротити такий строк до 10-15 днів.

Зауважимо, що проблеми у правозастосовчій практиці викликало питання можливості касаційного оскарження ухвали про забезпечення позову.

Зрештою Велика Палата Верховного Суду Постановою від 18 травня 2021 року роз'яснила положення процесуальних кодексів України щодо порядку 
оскарження ухвал про забезпечення позову. Зокрема, звертаючись до вимог КАС України щодо апеляційного та касаційного оскарження судових рішень, Верховний Суд зазначив, що загальні правила апеляційного оскарження в адміністративному судочинстві передбачають, що учасники справи, особи, які не брали участі у справі, якщо суд вирішив питання про їхні права, свободи, інтереси та (або) обов`язки, мають право подати апеляційну скаргу на рішення суду першої інстанції. Учасники справи, особи, які не брали участі у справі, якщо суд вирішив питання про їхні права, свободи, інтереси та (або) обов ‘зки, мають право оскаржити в апеляційному порядку ухвали суду першої інстанції окремо від рішення суду лише у випадках, передбачених статтею 294 цього Кодексу. Оскарження ухвал суду, які не передбачені статтею 294 цього Кодексу, окремо від рішення суду не допускається (стаття 293 КАС України).

У статті 294 КАС України зазначено, що окремо від рішення суду можуть бути оскаржені в апеляційному порядку, зокрема, ухвали суду першої інстанції щодо: забезпечення позову, заміни заходу забезпечення позову, скасування забезпечення позову, відмови у забезпеченні позову, відмови у заміні заходу забезпечення позову або скасуванні забезпечення позову (пункт 2 частини першої зазначеної вище статті).

Учасники справи, а також особи, які не брали участі у справі, якщо суд вирішив питання про їхні права, свободи, інтереси та (або) обов язки, мають право оскаржити в касаційному порядку рішення суду першої інстанції після апеляційного перегляду справи, а також постанову суду апеляційної інстанції повністю або частково у випадках, визначених цим Кодексом (частина перша статті 328 КАС України).

Щодо касаційного оскарження ухвали, то частиною другою статті 328 КАС України вказано, що у касаційному порядку можуть бути оскаржені ухвали суду першої інстанції про забезпечення позову, заміну заходу забезпечення позову, ухвали, зазначені у пунктах 3, 4, 12, 13, 17, 20 частини першої статті 294 цього Кодексу, після їх перегляду в апеляційному порядку.

Велика Палата Верховного Суду зазначила, що положення ГПК України, ЦПК України, КАС України, які регулюють апеляційне та касаційне оскарження судових рішень, прийнятих за наслідками розгляду заяви про забезпечення позову, містять текстові розбіжності. Ці розбіжності не є такими, що зумовлюють різний зміст відповідної процесуальної дії залежно від юрисдикції спору, а застосування наведених вище процесуальних норм має бути однаковим як для господарського, так і для цивільного судочинства.

Сукупний аналіз наведених вище процесуальних норм вказує на те, що підлягають перегляду в касаційному порядку ухвали суду першої інстанції про забезпечення позову, заміну заходу забезпечення позову, а також постанови суду 
апеляційної інстанції, якими такі ухвали залишено без змін.

Відповідно ухвали суду першої інстанції про відмову у скасуванні чи заміні заходів забезпечення позову, а також постанови суду апеляційної інстанції, якими такі ухвали залишено без змін, касаційному оскарженню не підлягають.

Процесуальні норми, які визначають обсяг права на касаційне оскарження таких ухвал (та, відповідно, постанов про залишення цих ухвал без змін, прийнятих апеляційним судом), є чіткими, зрозумілими, не викликають їх неоднозначного тлумачення та застосування.

При цьому в разі буквального застосування приписів процесуального законодавства щодо оскарження у касаційному порядку постанов суду апеляційної інстанції, прийнятих за наслідками перегляду в апеляційному порядку ухвали суду першої інстанції, вбачається їх фактичне розрізнення залежно від наслідків такого перегляду (залишено ухвали без змін, чи змінено їх або скасовано повністю чи частково).

За таких умов Верховний Суд констатував, що означені процесуальні критерії щодо допуску до перегляду судового рішення касаційним судом залежно від змісту судового рішення після зміни конституційної моделі інституту касаційного оскарження спричиняють неоднозначне розуміння та застосування норми закону в частині права на касаційне оскарження постанов суду апеляційної інстанції, якими залишено ухвали суду першої інстанції без змін, змінено їх або скасовано повністю чи частково [6].

До гарантій прав відповідача при забезпеченні позову віднесемо і передбачену статтею 157 КАС України можливість скасування судом заходів забезпечення позову 3 власної ініціативи або за вмотивованим клопотанням учасника справи.

В силу частини другої вказаної статті клопотання про скасування заходів забезпечення позову розглядається в судовому засіданні не пізніше п’яти днів 3 дня надходження його до суду.

Встановлена статтею 155 КАС України можливість заміни судом одного заходу забезпечення позову іншим за клопотанням учасника справи також розглядається нами як одна 3 процесуальних гарантій захисту прав відповідача при забезпеченні адміністративного позову.

Зауважимо, що питання про заміну одного заходу забезпечення іншим вирішується судом в судовому засіданні наступного дня після надходження до суду відповідного клопотання.

У рамках даного дослідження варто зазначити, що встановленому КАС України порядку розгляду заяви про забезпечення позову без участі сторін (ех parte) дорікають недотриманням принципу рівності сторін судового процесу: відповідач позбавлений права спростувати наявнісь підстав для забезпечення 
позову та надати відповідні докази в обгрунтування своєї позиції.

На наше переконання, правообмеження у даному випадку зумовлені саме цільовим призначенням забезпечення позову та компенсуються натомість зазначеними вище засобами. Крім того, відповідач не позбавлений права висловити свою позицію щодо забезпечення позову та надати відповідні докази під час підготовчого засідання у справі.

Однією з гарантій прав відповідача при забезпеченні позову є право такої особи на відшкодування збитків, заподіяних забезпеченням позову. За змістом частини першої статті 158 КАС України у випадку залишення позову без розгляду, а також закриття провадження у справі з підстав, визначених пунктами 2 та 4 частини першої статті 238 цього Кодексу, або у випадку ухвалення рішення суду щодо повної або часткової відмови у задоволенні позову відповідач або інша особа, чиї права або охоронювані законом інтереси порушені внаслідок вжиття заходів забезпечення позову, має право на відшкодування збитків, заподіяних забезпеченням позову, за рахунок особи, за заявою якої такі заходи забезпечення позову вживалися.

Разом 3 тим, необгрунтованим видається покладення відшкодування збитків відповідача на особу, за заявою якої такі заходи забезпечення позову вживалися, адже рішення про забезпечення позову приймає саме суд - i саме судове рішення про вжиття заходів забезпечення позову має зобов'язальну силу із відповідними правовими наслідками. Беззастережне ж покладення відповідальності на особу, яка реалізувала своє право на подання заяви про вжиття заходів забезпечення позову зрештою може призвести до нівелювання функції забезпечення позову через відмову заявників від ініціювання заходів забезпечення позову.

Крім того, відшкодування шкоди $є$ видом цивільно-правової відповідальності, а отже- для його застосування необхідними $є$ наявність усіх елементів складу правопорушення: протиправної поведінки, дії чи бездіяльності особи, завданої шкоди, вини особи, яка завдала шкоди та причинного зв’ язку між протиправною поведінкою особи та завданими збитками.

Деякими науковцями пропонується у зв'язку з цим застосування спрощеного підходу та відшкодування збитків, завданих забезпеченням позову, безвідносно до вини особи, яка ініціювала вжиття заходів забезпечення позову [7, с.18-19].

Законодавцем не конкретизовано порядок відшкодування відповідачеві або іншій особі, чиї права або охоронювані законом інтереси порушені внаслідок вжиття заходів забезпечення позову збитків, заподіяних забезпеченням позову.

Наразі це питання може бути вирішене шляхом подання окремого адміністративного позову.

Видається однак, що більш ефективним було б упровадження механізму вирішення питання щодо відшкодування збитків, заподіяних забезпеченням 
позову, судом, який розглядав відповідну справу та вживав заходів забезпечення позову.

Наприклад, за аналогією з діючим нині порядком розподілу судових витрат, позивачеві встановлюється певний строк для подання заяви про відшкодування збитків, завданих забезпеченням позову, перебіг якого обраховуватиметься від дня постановлення рішення по суті справи, ухвали про залишення позову без розгляду, а також закриття провадження у справі.

У разі подання такої заяви у встановлений строк, суду належатиме вирішити питання про відшкодування збитків.

У правничій спільноті наразі обговорюється питання щодо доцільності впровадження в адміністративному судочинстві інституту зустрічного забезпечення позову за аналогією 3 цивільним та господарським процесами.

Зустрічне забезпечення позову аокликане запобігати зловживанням позивача своїми процесуальними правами та є певною гарантією збереження «status-quo» між сторонами до ухвалення остаточного рішення суду за суттю справи [8].

Так, чинна редакція ЦПК України розглядає зустрічне забезпечення як механізм захисту прав відповідача від можливих збитків, завданих забезпеченням позову.

Водночас, з огляду на передбачені КАС України способи забезпечення позову, упровадження зустрічного забезпечення в адміністративному судочинстві видається малоефективним: дієвий правовий механізм зустрічного забезпечення радше спрямований на захист матеріальних інтересів відповідача, тоді як предметом адміністративного судочинства охоплюється значно ширше коло суспільних відносин. За таких умов можна поділити думку А.Марцинкевича, який розглядає можливість впровадження зустрічного забезпечення в адміністративному судочинстві у справах за позовами про оскарження рішень суб'єктів владних поноважень про застосування штрафних (фінансових) санкцій [9, с. 176; 10; 11].

Висновки. Підсумовуючи викладене, зазначимо, що існуюче законодавче регулювання інституту забезпечення позову в адміністративному судочинстві характеризується наявністю достатніх захисних та компенсаторних механізмів для відповідача, які гарантують дотримання принципів рівності сторін та диспозитивності. Проте, окремі аспекти реалізації таких механізмів потребують подальшоїнакуової розробки та законодавчого удосконалення.

\section{Лimepamypa:}

1. Берназюк Я. Конституційний принцип рівності та його особливості в адміністративному судочинстві. URL: https://sud.ua/ru/news/blog/143839-konstitutsiyniy-printsiprivnosti-ta-yogo-osoblivosti-v-administrativnomu-sudochinstvi

2. Константий О. В. Захист прав фізичних та юридични.х осіб в адміністративному судочинстві: проблеми теорії і практики : автореф. дис. ... д-ра юрид. наук : 12.00.07, Нац. юрид. ун-т ім. Ярослава Мудрого, Харків, 2015. 43 с. 
3. Банчук О.А., Куйбіда О.Р. Вимоги статті 6 Конвенції про захист прав і основних свобод до процедури здійснення судочинства. К. : ІКЦ «Леста», 2005. 116 с.

4. Шухатян X. О. До питання захисту інтересів відповідача при реалізації заходів забезпечення позову у господарському процесі. Право і суспільство. 2013. № 6.2. - С. 135-139.

5. Лабань О. О. Захист прав та інтересів відповідача під час забезпечення позову в цивільному судочинстві. Науковий вісник публічного та приватного права. 2019. Т. 2, № 3. C. 84-89.

6. Постанова Великої Палати Верховного Суду від 18.05.2021 р. у справі № 914/1570/20. URL: https://reyestr.court.gov.ua/Review/97967349 (дата звернення: 01.08.2021).

7. Буга Г.С. Забезпечення позову в цивільному процесуальному праві України. автореф. дис. ... канд.юрид. наук: 12.00.03 / Харків. Нац. Унів-т. Внутр. Справ. Харків, 2012. 21с.

8. Луспеник Д.Д. Зустрічне забезпечення. Кілька складних питань щодо застосування нового інституту, 3 якими стикнуться судді. Закон і бізнес. 2017. № 34 (1332). URL: http://zib.com.ua/ua/print/130073kilka_skladnih_pitan_schodo_zastosuvannya_zustrichnogo_zabez.html.

9. Марцинкевич С. А. Правові засади забезпечення позову в адміністративному судочинстві : дис. ... д-ра філософії в галузі права : 081. Київ, 2021. 239 с.

10. Stryukov, V., \& Hromtseva , O. (2019). Analysis of key competences in vocational education. Journal of Scientific Papers «Social Development and Security»,9(5), 94 . https://doi.org/10.33445/sds.2019.9.5.6

11. СТрюков, В. (2020). УПРАВЛІННЯ ПРОЦЕСОМ ФОРМУВАННЯ КОМУНІКАТИВНОЮ КОМПЕТЕНЦІЕЮ СЕРЕДНЬОГО МЕДИЧНОГО ПЕРСОНАЛУ. Економіка та суспільство, (22). https://doi.org/10.32782/2524-0072/2020-22-58

\section{References:}

1. Bernaziuk, Ya. Konstytutsiinyi pryntsyp rivnosti ta yoho osoblyvosti v administratyvnomu sudochynstvi [The constitutional principle of equality and its features in administrative proceedings]. (n.d.). sud.ua. Retrieved from https://sud.ua/ru/news/blog/143839-konstitutsiyniy-printsip-rivnosti-tayogo-osoblivosti-v-administrativnomu-sudochinstvi [in Ukrainian].

2. Konstantyi, O. V. (2015) Zakhyst prav fizychnykh ta yurydychny.kh osib v administratyvnomu sudochynstvi: problemy teorii i praktyky [Protection of the rights of individuals and legal entities in administrative proceedings: problems of theory and practice]. Extended abstract of Doctor's thesis. Kharkiv: [in Ukrainian].

3. Banchuk, O.A., \& Kuibida, O.R. (2005). Vymohy statti 6 Konventsii pro zakhyst prav i osnovnykh svobod do protsedury zdiisnennia sudochynstva [Requirements of Article 6 of the Convention for the Protection of Human Rights and Fundamental Freedoms to the judicial procedure]. Kiev: : IKTs «Lesta» [in Ukrainian].

4. Shukhatian, Kh. O. (2013). Do pytannia zakhystu interesiv vidpovidacha pry realizatsii zakhodiv zabezpechennia pozovu u hospodarskomu protsesi [On the issue of protection of the defendant's interests in the implementation of measures to ensure the claim in the economic process]. Pravo i suspilstvo - Law and society, 6.2, 135-139 [in Ukrainian].

5. Laban, O. O. (2019) Zakhyst prav ta interesiv vidpovidacha pid chas zabezpechennia pozovu $\mathrm{v}$ tsyvilnomu sudochynstvi [Protection of the rights and interests of the defendant during the securing of the claim in civil proceedings]. Naukovyi visnyk publichnoho ta pryvatnoho prava - Scientific Bulletin of Public and Private Law, 3, 84-89 [in Ukrainian]. 
6. Postanova Velykoi Palaty Verkhovnoho Sudu vid 18.05.2021 r. u spravi № 914/1570/20. URL: https://reyestr.court.gov.ua/Review/97967349 (data zvernennia: 01.08.2021).

7. Buha, H.S. (2012). Zabezpechennia pozovu v tsyvilnomu protsesualnomu pravi [Securing a claim in the civil procedural law of Ukraine ] Extended abstract of candidate's thesis. Kharkiv: [in Ukrainian].

8. Luspenyk, D.D. (2017). Zustrichne zabezpechennia. Kilka skladnykh pytan shchodo zastosuvannia novoho instytutu, z yakymy styknutsia suddi [Counter support. Some difficult questions about the application of the new institution that judges will face]. Zakon $i$ biznes - Law and business, 34 (1332). Retrieved from: http://zib.com.ua/ua/print/130073kilka_skladnih_pitan_schodo_ zastosuvannya_zustrichnogo_zabez.html. [in Ukrainian].

9. Martsynkevych, S. A.(2021). Pravovi zasady zabezpechennia pozovu v administratyvnomu sudochynstvi [Legal bases of securing a claim in administrative proceedings]. Extended abstract of Doctor's thesis. Kiev: [in Ukrainian].

10. Stryukov , V., \& Hromtseva , O. (2019). Analysis of key competences in vocational education. Journal of Scientific Papers «Social Development and Security»,9(5), 94 . https://doi.org/10.33445/sds.2019.9.5.6

11. Strjukov, V. (2020). UPRAVLINNJa PROCESOM FORMUVANNJa KOMUNIKATIVNOJu KOMPETENCIEJu SEREDN"OGO MEDIChNOGO PERSONALU [MANAGEMENT OF THE PROCESS OF FORMATION OF COMMUNICATIVE COMPETENCE OF NURSING MEDICAL STAFF]. Ekonomika ta suspil'stvo - Economy and society (22). https://doi.org/10.32782/2524-0072/2020-22-58 